\title{
A REFUTATION OF SEVERAL MUSLIM APOLOGETIC ARGUMENTS AND A POWERFUL ARGUMENT AGAINST GOD'S AUTHORSHIP OF THE QURAN
}

\author{
RAPHAEL LATASTER * \\ University of Sydney
}

\begin{abstract}
Having spent many years researching the best apologetics Christian philosophers could offer, I recently started examining Muslim apologetics. Focussing on the arguments for the Islamic God's existence by popular Muslim apologist Hamza Andreas Tzortzis, I conclude that they are terrible, and are not of the same quality as the best arguments for the truth of Christianity. Furthermore, I converted one of these into a powerful argument against mainstream Islamic/Quranic theism, which can be utilised by atheists and Christians alike; and just about anybody else
\end{abstract}

KEY WORDS: Islam Apologetics, Muslim arguments, Miracles, Quranic challenge, Christianity

\section{Introduction}

As an atheistic philosopher who has spent many years seeking out and critiquing the best arguments for the truth of Christianity, I have often been asked-and even playfully mocked-by my Christian friends about my lack of focus on Muslims' arguments. Some wondered if I am scared of Muslims, especially since the Islamist attack on the offices of Charlie Hebdo in 2015. Yet others wondered if I am scared of mainstream leftists who defend Islam at all costs, and would portray me as a bigot and attempt to get me fired. While these are certainly worthy of consideration in today's climate, the simple truth is far less exciting: circumstance.

Having been a Christian in the past, and studied Christianity at university (partly in an attempt to salvage by waning faith), I am simply more familiar with Christian arguments. But I do agree that other religious traditions should not get a free pass as I, and many colleagues, focus on critiquing the arguments of Christians. Circumstance again reared its ugly head, however, as I declined a proposal to debate an extremist Muslim who was previously banned from speaking at my university. And in 2018, I was invited to debate with up and coming Muslim apologist Hamza Andreas Tzortzis on the topic

* RAPHAEL LATASTER (PhD 2017, University of Sydney) is an associate lecturer in Religious Studies at the University of Sydney, Australia. 
of the Islamic God's existence. After spending much time preparing for this debate, the topic was drastically changed, again leading to the event being cancelled. However, this work shall not go to waste. Following is a quick refutation of three of Tzortzis' arguments-or rather several refutations from different religious and irreligious perspectives_and his approach to arguing for the truth of Islamic theism in general. Interestingly, one of these refutations led me to develop a very powerful argument against Islamic theism.

\section{The Cosmological Argument}

Invoked often in Tzortzis' apologetics, particularly in his debates, is his cosmological argument:

1. The universe is finite.

2. Finite things could have come from nothing, created themselves, been ultimately created by something created, or been created by something uncreated.

3. They could not have come from nothing, created themselves, or have been ultimately created by something created.

4. Therefore, they were created by something uncreated (Tzortzis 2018a).

Many atheists and also Christians would immediately take issue with the first premise, even if they do think that the world began to exist. Tzortzis defends this premise by using analogies to demonstrate the apparent absurdity of the universe:

Conceptually, the universe is no different to the bag of balls or the stack of cubes I have explained above. The universe is real. It is made up of discrete physical things. Since the differentiated infinite cannot exist in the real world, it follows that the universe cannot be infinite. This implies that the universe is finite, and since it is finite it must have had a beginning (Tzortzis 2018a).

Arguing from absurdity is itself fraught with difficulty, especially as Tzortzis' burden is very great as he unambiguously shuns the probabilistic approach, finding that his beliefs should not have to conform to the evidence (see Tzortzis and Krauss 2018, a debate), but it seems obvious that the universe being finite in terms of physical objects is not equivalent to saying that the universe cannot be eternal and uncreated. Tzortzis also appeals to the Big Bang, but that is more suited to a probabilistic argument, and only asserts that the universe began to expand at some point-not that it had a proper beginning, especially ex nihilo. Various non-theists besides naturalists may also take issue with this argument, for its inability to lead directly to theism. For example, deists and polytheists may also believe that the universe was created 
by a Creator, or Creators, finding that this argument does not at all argue for theism. Monists such as pantheists, panentheists, and pandeists would be similarly unswayed. Other theists, such as Christian theists, would also be comforted that this argument does not at all lead to an exclusively Muslim view of God. Why couldn't the Christian God be responsible for the creation of this 'finite' universe?

If this critique seems rather brief, it is because a more thorough refutation is simply unnecessary. Tzortzis explicitly utilises a non-probabilistic approach, which places a great methodological burden on himself, yet he does not prove his premises; his argument also does not necessarily lead to the God of theism. This is not a great start, although Christians wondering how Tzortzis specifically argues for the truth of Islamic theism will find his other arguments rather amusing.

\section{The Quranic Argument}

One of Tzortzis' go-to arguments for moving from theism to a specifically Islamic theism is his argument from the inimitability of the Quran, derived from a challenge purportedly set by God himself (Quran 2:23-24, 10:38, $11: 13,17: 88,52: 33-34)$ :

1. The Qur'an presents a literary and linguistic challenge to humanity.

2. The 7th century Arabs were best placed to challenge the Qur'an.

3. The 7th century Arabs failed to do so.

4. Scholars have testified to the Qur'an's inimitability.

5. Counter-scholarly testimonies are not plausible, as they have to reject the established background information.

6. Therefore (from 1-5) the Qur'an is inimitable.

7. The possible explanations for the Qur'an's inimitability are authorship by an Arab, a non-Arab, Muhammad or God.

8. It could not have been produced by an Arab, a non-Arab or Muhammad.

9. Therefore, the best explanation is that it is from God (Tzortzis 2018b).

Tzortzis elaborates on this challenge:

When the [Arabs] were unable to produce a single chapter like [the Qur'an] despite there being the most eloquent rhetoricians amongst them, [the Prophet] openly announced the failure and inability [to meet the challenge] and declared the inimitability of the Qur'an. Then God said, Say, if all of humankind and the jinn gathered together to produce the like of the Qur'an, they could not produce it-even if they helped one another... 
Challenge accepted! The problems with this argument are manifold, andagain-we needn't discuss them all here. One is the naïve acceptance of testimonies about very learned men apparently trying and failing to imitate the Quran. It is as if Tzortzis is completely ignorant that there is a great historical and contemporary rival to Islam, Christianity, which also makes use of testimony-and in a much more refined and sophisticated way. We obviously have no good reason to trust what these figures, or contemporary Islamic scholars, have to say about the inimitability of the Quran. And one clear reason is that this premise is undeniably wrong. The Quran is most certainly not inimitable.

In his debate with Tzortzis, physicist Lawrence Krauss claimed to have randomly generated several verses from the Quran. Krauss reiterated this claim to me personally, but we need not take his testimony, or even my testimony of yet more testimony, as Gospel. Barely trying, and having very little knowledge of Information Technology, I personally managed to randomly generate a verse of the Quran. That verse is Quran 55:64, consisting of just one term, 'dark green'; this verse is also surrounded by several other very short verses. Clearly, the Quran is not so inimitable. Even if my testimony is doubted, what I have claimed here is certainly possible.

The Quranic challenge usually refers to chapters, however, so perhaps Tzortzis has an out. Unfortunately for him, this sanctuary immediately falls away with some rudimentary knowledge of the Quran-Perhaps Muslim apologists are relying on non-Muslims' relative ignorance of Islam. Many chapters consist of only a few short verses, and 15-20 words, such as Quran 112 (Surah Al-Ikhlas). And if the shortest verses and chapters can be produced randomly, so too for the longest verses and chapters, and even for the entire Quran. And not just something that resembles the Quran (one example of a book mimicking the Quran is the anonymously authored The True Furqan [1999]). The Quran itself. Clearly, the Quran is not inimitable. The Quran, and documents like the Quran, can be produced, even when the would be forger is an ignoramus randomly choosing words, or even letters or markings, rather than a brilliant literary mind who deftly weaves together poetry, philosophy, and prophecy, as is the case with many other religious texts-such as the Bhagavad Gita, or the Tanakh. With Christians and other religious people likewise considering their holy texts to be aesthetic, divine, wise, unique, and so forth, Tzortzis needs to do a lot more to demonstrate the Quran's divine authorship.

Also bear in mind that Tzortzis' explicitly non-probabilistic approach entails that he must demonstrate the impossibility of alternative explanations. If his premises are unknown to be true, the same applies for his conclusion. Merely claiming that nobody but God can produce parts of the Quran or similar documents is of course not sufficient. Even if he could demonstrate 
that mimicking the Quran is very improbable, which we now know is definitely not the case, he would need to show that it is impossible. That he clearly has not done.

Another problem for the Quranic challenge is that the Quran implicates and effectively contradicts itself. It asserts that only God can produce the Quran and documents like it, yet Quran 28:48-49 and 46:10-12 likens the Quran to the Torah. While Muslims may believe that the Torah also comes from God, their belief that the Bible has been corrupted aside, mainstream scholarship understands that the Torah was written by humans-many humans, fallible and even wicked humans, over many years, in fact; this potentially supports the Muslim belief in the Bible's having been corrupted, but also seems to defeat the Quranic challenge (for some evidence of the Torah's 'corruption', see Dershowitz, Akiva, Koppel, and Dershowitz 2015).

Interestingly, I would go so far as to say that this all makes for a good argument against Islam, and against the existence of the Islamic God. Surely the all-knowing God of theism would not lay down a challenge that was so easily met. Surely such a combative God would ensure that the Quran did not include several chapters consisting of only a few words! It is unfathomable that an all-knowing and all-powerful God would make such a silly error. It is unthinkable that a mere mortal like myself could so easily defeat Allah, the Islamic God, in a battle of wits. Perhaps a divine being was behind the authorship of the Quran. It surely wasn't God.

With that in mind, let us recall the interesting story of the Satanic Verses. According to traditional Islamic accounts, Muhammad's Quranic verses were imitable after all, which seems to contradict the Quranic challenge and Tzortzis' argument, particularly with Tzortzis' credulity regarding testimonies. And yet, this is not the only interesting aspect of this story. Given that the local Meccan Pagans could produce passages similar to Quranic passages, Muhammad longed for more revelations, more passages that could finally convince the local Meccan Pagans. He miraculously received them, and they indicated that the Pagans could still honour certain other gods. Muhammad, Muslims, and Pagans alike were delighted. However, later, Muhammad declared that this revelation actually came from the Devil. As such, the Quran effectively had to be edited. This necessarily leads objective critics to much justifiable scepticism about whether other parts of the Quran were inspired by Satan, what has been changed, whether the 'right bits' were changed, and so forth. Indeed, if Satan could inspire Muhammad to write part of the Quran, why not all? Further, non-Muslims may wonder if it is wise to follow a prophet who could not tell the difference between a revelation from God and a revelation from Satan, and who so easily accepted a form of polytheism, violating the all important Shahada [One of the famed Five Pillars of Islam, a 
statement asserting that 'There is no god but God, and Muhammad is the messenger of God.' For more on the Satanic Verses, see Ahmed 1998].

There are other relevant issues that can be considered, such as the vagueness of the criteria of the Quranic challenge (the challenge is quite nebulous, and one could easily claim that the following challenge is equally valid: It is impossible to produce something as amazing and unique as The Hitchhiker's Guide to the Galaxy. Personally, I think the Daodejing of the Taoists is more impressive and unique. Not only for its profound contents and its superior alignment with the currently available evidence, but also for its famed conciseness); the Quran's reliance on oral transmission, which historical research reveals to be very unreliable, now supported by modern cognitive science; problems involved in the shift from oral to written forms; the Quran's possibly plagiarising earlier Pagan, Jewish, and Christian texts; the Quran's building on incorrect beliefs, such as the existence and actions of certain biblical patriarchs; and the Quran's containing many claims now refuted by empirical evidence; but such discussion is now hardly necessary [Nor is it particularly relevant to bring up, as Tzortzis has in several debates, that the Quran probably influenced the development of Arabic, particularly as the Vedic scriptures quite likely influenced the development of Sanskrit. Shakespeare, too, has greatly influenced the English language, in terms of grammar and vocabulary].

\section{The Quranic Argument Against Islamic Theism}

The 'revelation' that the Quran contains such an easily overcome challenge can be expressed more formally into a probabilistic argument, which can also work non-probabilistically:

1. If written by God and accurately transmitted, the Quran would not contain a divine challenge that is easily overcome.

2. The Quran does contain a divine challenge that is easily overcome.

3. Therefore, the Quran was not written by God, or has not been accurately transmitted, or both.

Whichever conclusion applies, mainstream Islam, which is theistic and is centred on the Quran, is critically undermined (note that not all forms of Islam would be overcome, such as very liberal forms). God either did not author the Quran, or did, though God's Quran differs from the forms of the Quran available today. This is a powerful argument against contemporary Islamic theism that may not only be used by atheists and non-theists, but also by different kinds of theists, such as mainstream Jews and Christians, which they may especially appreciate given mainstream Islam's stance on the corruptions 
of the Bible. Even those identifying as liberal Muslims could use this argument to counter their more conservative-and more numerous-cousins.

\section{The Muhammadean Argument}

Tzortzis also produces an argument to demonstrate that Muhammad's claim to prophethood was true. Another odd choice for an argument given Tzortzis' non-probabilistic approach:

1. Muhammad was a liar, deluded, or speaking the truth.

2. He could not have been a liar or deluded.

3. Therefore, he was speaking the truth (paraphrased from his video presentation, available at Tzortzis 2018c.).

Without any decisive evidence, Tzortzis claims that Muhammad being a liar is 'counter-intuitive'. He further claims that this opposes the testimony of even Muhammad's enemies. He finds it decisive that Muhammad was apparently 'so humble'. Tzortzis does not feel the need to fully justify these claims, apparently finding it sufficient that some people at sometime made the claim. There are many problems with such an approach, not least being that adherents of other religions often likewise produce glowing reports about their respective founders and central claims. For example, Christians tend to think that Jesus was wonderful, and so do many non-Christians! Tzortzis goes on to make the starting claim that 'to claim he is a liar is like claiming no one has spoken the truth'. None of this is particularly compelling, and Muhammad may well have been a liar. Granting that he was genuine, however, as many other religious founders no doubt were, there are other possibilities.

So Tzortzis duly attempts to dismiss the possibility that Muhammad was simply mistaken, which he calls 'deluded'. Tzortzis mentions 'so many prophecies' of Muhammad that apparently came true. For example, he refers to Muhammad's alleged prediction of the Mongol attacks. This is not in the Quran, and the source is not clarified, nor is the veracity thereof verified. Tzortzis similarly refers to another non-Quranic prophecy apparently about 'Arabs competing in the construction of tall buildings', with, again, no argument for the reliability of his source. Interestingly, he himself acknowledges that this may be a self-fulfilling prophecy, though without fully appreciating the possibility that some wealthy Arabs had the ability to fulfil a prophecy, and thought 'Might as well!' Tzortzis indicates that coincidences regarding these prophecies are improbable, which goes directly against his non-probabilistic approach. In any case, this is not entirely relevant, as one could still make correct predictions, and otherwise be a clever and wonderful person, while still being mistaken on matters like a revelation of God. Tzortzis also admits his reliance on a 'weak tradition... in terms of authenticity', which 
should have made him aware of the uncertainty regarding textual authenticity and the necessarily probabilistic conclusions that can be drawn from them. He refers to a presumably reliable 'chain of narration', apparently oblivious to similar claims - typically doubted by critical scholars-made by competing religious adherents.

Now this argument is clearly derived from influential Christian theologian C. S. Lewis' Trilemma (that Jesus was liar, lunatic, or lord), to which Bart Ehrman added a fourth element: legend (Ehrman meant not that Jesus was a legend, but that legendary claims were made about him, as seen in Ehrman 2018). Tzortzis is aware that critics could claim these accounts are legendary, and he says this would be 'gross ignorance on the way that Islamic scholars preserved history'. This simply sounds like special pleading, considering that similar claims are made concerning rival religions. Tzortzis then turns to the possible objection that Muhammad lied for noble reasons, judging that $\mathrm{Mu}-$ hammad would have been better off not lying about his prophethood, which is entirely speculative, and reminiscent of the misuse of the embarrassment and dissimilarity criteria by Christian apologists; this is also very counterintuitive given that Muhammad's claim has clearly been crucial to the widespread dissemination-and acceptance-of his views, and the increase in his power and reputation during his own lifetime, which is so often lacking regarding the lives of other religious founders. Tzortzis then goes on to express admiration for Muhammad's teachings, and this could of course apply to other religious figures as well. Teachings of all religious figures are cherished by followers, and often by non-followers as well. Also, many of these teachings were not actually unique to Muhammad.

Tzortzis concludes with the frankly absurd claim that 'Epistemically, if you reject the prophet Muhammad (upon him be peace) as a prophet, it's epistemically equivalent of rejecting that your mother gave birth to you.' He repeats the common claim that if we reject such and such testimony, we must reject all testimonies, apparently unaware that some claims are more believable than others; and once again astonishingly ignorant of the facts that rival religionists can make similar claims, and that he is in effect trying to utilise the probabilistic approach that he so disdains.

\section{Conclusion}

Keen to see if arguments for Islamic theism by popular apologists are compelling, I discovered that several of them are far beyond a level necessary to convince non-resistant non-believers and adherents of other religions. Furthermore, one of these arguments, concerning Allah's challenge to non-believers in the Quran, was readily converted into a strong probabilistic argument against Islamic theism. It is unthinkable that the God of theism would so recklessly set a challenge that would be easily met by mere mortals, so that 
it can be concluded that the Quran-at least the one available today-was certainly not authored by the God of theism. If God exists, it certainly did not reveal itself through the Quran.

\section{Bibliography}

(Please note that for consistency, the years given for website sources are the access years, since many do not disclose the publication year.)

Ahmed S (1998) Ibn Taymiyyah and the Satanic Verses. Studia Islamica 87(1): 67-124.

Dershowitz I, Akiva N, Koppel M, Dershowitz N (2015) Computerized Source Criticism of Biblical Texts. Journal of Biblical Literature 134(2): 253-271.

Ehrman B (n.d.) https://ehrmanblog.org/the-problem-with-liar-lunatic-or-lord-for-members, accessed 2018.

Tzortzis H (n.d.) http:/www.hamzatzortzis.com/the-qurans-argument-forgods-existence, accessed 2018a.

Tzortzis H (n.d.) http://www.hamzatzortzis.com/gods-testimony-the-divine-authorship-of-the-quran (n.d.) accessed 2018b.

Tzortzis H, http://www.hamzatzortzis.com/the-prophetic-truth-proving-muhammads-prophethood (n.d.) accessed 2018c.

Tzortzis H, Krauss L, https://www.youtube.com/watch?v=uSwJuOPG-4FI, accessed 2018.

*** (1999) The True Furqan. Enumclaw, WA: Wine Press Publishing. 